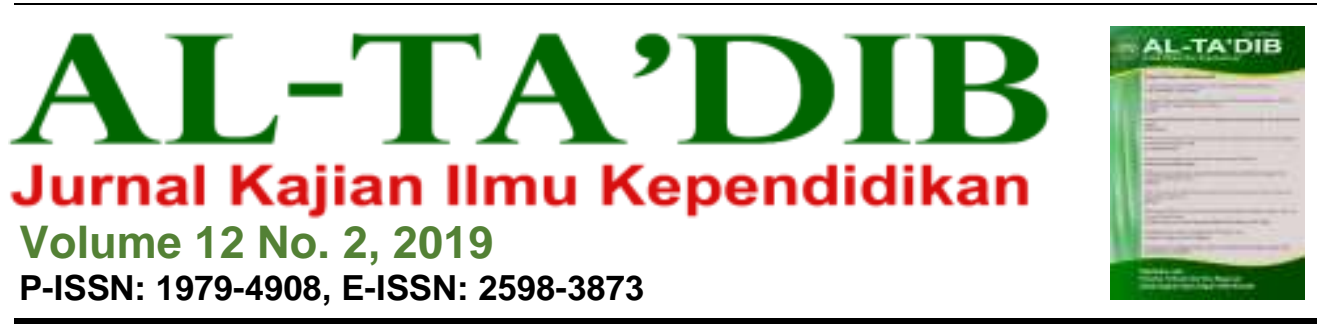

\title{
Internalisasi Pendidikan Karakter dalam Pembelajaran Pendidikan Agama Islam
}

\author{
Benny Prasetya ${ }^{1}$, Saifuddin ${ }^{2}$ \\ ${ }^{1}$ STAI Muhammadiyah Proboliggo, Indonesia. E-mail: prasetiyabenny@gmail.com \\ ${ }^{2}$ STAI Muhammadiyah Proboliggo, Indonesia. E-mail: saifuddin653@yahoo.com
}

\begin{tabular}{l} 
INFORMASI ARTIKEL \\
\hline Kata Kunci: \\
Internalisasi; Pendidikan \\
Agama Islam, pendidikan \\
karakter \\
Cara Mensitasi: \\
Prasetya, B., \& Saifuddin. \\
(2019). Internalisasi \\
pendidikan karakter dalam \\
pembelajaran Pendidikan \\
Agama Islam. Al- \\
Tadib:Jurnal Kajian Ilmu \\
Kependidikan, 12(2), 322- \\
333. \\
DOI: \\
http://dx.doi.org/10.31332/ \\
atdbwv12i2.1531
\end{tabular}

\begin{abstract}
ABSTRAK
Penelitian ini dilatarbelakangi urgensi pendidikan karakter dalam membentuk akhlak mulia dan cerdas sebagaimana tujuan pendidikan nasional. Paradigma yang dibangun dalam penelitian ini menggunakan kualitatif dengan pendekatan fenomenologis. Subyek penelitian adalah kepala sekolah, guru, dan siswa sekolah menengah pertama menggunakan teknik purposive. Proses pengumpulan data menggunakan pengamatan nonpartisipan, wawancara mendalam dan dokumentasi. Hasil penelitian menunjukkan bahwa nilai-nilai pendidikan karakter yang ditanamkan di sekolah melalui Pendidikan Agama Islam (PAI) adalah nilai kejujuran, taat kepada agama, disiplin, kerjasama, toleransi, cinta ilmu, kepedulian, dan tanggung jawab. Wujud penanaman nilai pendidikan karakter di sekolah menggunakan metode keteladanan dan pembiasaan dengan mengadakan kegiatan keagamaan seperti hadrah dan shalat Jumat bergilir yang digunakan untuk memberikan keterampilan khusus kepada anak didik untuk bekal di masa depan. Evaluasi internalisasi pendidikan karakter melalui PAI dilakukan dengan observasi langsung, hasil penugasan, partisipasi kegiatan, dan lain-lain.
\end{abstract}




\section{ARTICLE INFO}

Keywords:

Character education; internalization; Islamic religious subject

How to cite:

Prasetya, B., \& Saifuddin. (2019). Internalisasi pendidikan karakter dalam pembelajaran Pendidikan Agama Islam. $A l$ -

Tadib:Jurnal Kajian Ilmu Kependidikan, 12(2), 322333.

DOI:

http://dx.doi.org/10.31332/ atdbwv12i2.1531

\begin{abstract}
This research is motivated by the urgency of character education in shaping noble and intelligent character as it becomes the goal National Education. This qualitative study uses phenomenological approach. The participants are the headmaster, teachers, and students at a secondary junior school. Subjects were chosen using purposive technique. The data collection process uses non-participant observation, in-depth interviews, and documentation. The study reveals that the values of character education embedded in the school through Islamic religious subject are honesty, obedience to religion, discipline, cooperation, tolerance, love of knowledge, care, and responsibility. Some ways to embed the character education at the school are by engaging students to religious activities such as hadrah and scheduled Friday prayers which will be useful for them in the future. Evaluating the internalization of character education through Islamic religious subject can be done through direct observation, assignments, participation in activities, etc.
\end{abstract}

\section{Pendahuluan}

Pendidikan karakter menjadi tema besar dalam penerapan kurikulum 2013 untuk memberikan penanaman nilai-nilai karakter dalam proses pembelajaran sehingga setiap pengetahuan yang diperoleh bisa menghadirkan akhlak, kemandirian, kedisiplinan, kejujuran dalam perilaku peserta didik setiap hari. Lembaga pendidikan diharapkan memiliki model yang terbaik dalam proses internalisasi karakter pada peserta didik sehingga output dari proses pembelajaran bukan hanya pada aspek kecerdasan kognitif namun lebih kepada nilai-nilai karakter (Astra, 2018; Kosim, 2019; Ma'arif, 2018; Mubarok, 2019a). Karenanya, dalam proses implementasi pendidikan karakter harus bisa diintegrasikan di semua mata pelajaran (Kosim, 2019; Wijayanti, 2018).

Pendidikan karakter merupakan tujuan terpenting dalam proses pendidikan untuk membentuk pribadi untuk memiliki perilaku yang baik. (Mubarok, 2019a; Nurajizah \& Rahayu, 2019). Pendidikan karakter dapat diterapkan di dalam keluarga maupun sekolah (Puspita, 2019). Seiring dengan perkembangan zaman, pendidikan yang hanya berbasis hard skill dan menghasilkan lulusan yang berprestasi dalam bidang akademik harus mulai dibenahi. Proses pembelajaran yang dikembangkan di sekolah membutuhkan 
aspek pengembangan soft skill (interaksi sosial). Pengembangan ini dilakukan dengan tujuan siswa mampu memilki daya saing yang memiliki etika. Implementasi pendidikan soft skill dapat dilakukan pada pembinaan mentalitas peserta didik (Wijayanti, 2018).

Pendidikan karakter sangat mendesak untuk diterapkan mengingat persoalan imoralitas terus meningkat seperti perkelahian, korupsi, seks bebas, narkoba, pencurian dan perilaku menyimpang lainnya (Fitri, 2018; Mubarok, 2019b). Seringkali indikator-indikator tersebut menguatkan semakin tidak efektifnya peran pendidikan dalam arti luas (sekolah, lingkungan keluarga dan lingkungan sosial) (Prasetiya, Rofi, \& Setiawan, 2018). Salah satu indikator lain yang menunjukkan adanya krisis gejala rusaknya karakter bangsa yakni rendahnya penerapan nilai pendidikan agama dan nilai moral dalam perilaku siswa. Upaya yang dilakukan dalam proses pembentukan karakter di sekolah harus disesuaikan dengan budaya bangsa melalui pembiasaan (habituasi) dalam kehidupan, seperti: religius, kejujuran, sikap disiplin, toleransi, karakter etos kerja, sikap cinta damai, dan rasa tanggung jawab yang tinggi (Bali \& Fadilah, 2019; Kosim, 2019). Pembiasaan itu bukan hanya mengajarkan pengetahuan tentang hal-hal yang benar dan salah, akan tetapi juga mampu mengajarkan nilai yang baik dan tidak baik, serta dilakukan dari lingkup terkecil seperti keluarga sampai dengan cakupan yang lebih luas di masyarakat.

Sekolah dituntut untuk mampu membentuk karakter siswa melalui kegiatan pembelajaran di kelas maupun di luar kelas. Sekolah diharapkan mampu melakukan upaya-upaya kuratif, preventif, promotif dan rehabilitatif dalam pendidikan nilai. Peran sekolah sebagai tempat pembentukan karakter siswa dirasa penting dan memiliki pengaruh yang cukup besar. Guru dituntut untuk dapat terus mengembangkan diri dan mampu menjadi teladan bagi siswa untuk membentuk karakter yang baik. Pendidikan karakter merupakan salah satu aspek penting di dalam proses pendidikan yang diterima peserta didik (Jumala \& Abubakar, 2019). Tetapi nampaknya pembelajaran di sekolah atau madrasah lebih memrioritaskan ranah kognitif dan kurang menaruh perhatian pada ranah afektif. Sejatinya pendidikan bukan hanya transfer of knowledge namun transfer of value yang menjadi bagian penting untuk membangun sikap (Prasetiya et al., 2018; Yunarti, 2017). Penanaman nilai dan pembentukan sikap merupakan bagian dari pembelajaran ranah afektif untuk membentuk nilai kejujuran, integritas, kepercayaan diri dan sifat-sifat lainnya ke dalam diri peserta didik.

Sebagai lembaga pendidikan umum SMPN 1 Bantaran Kabupaten Probolinggo terus mencoba untuk menginternalisasi nilai-nilai pendidikan karakter melalui serangkaian kegiatan keagaamaan di sekolah yang tersusun dalam perencanan tahunan. Siswa SMPN 1 Bantaran Kabupaten Probolinggo memiliki karakter yang beragam. Banyak diantara mereka yang belum mantap 
dari segi kepribadian. Mereka tergolong masih dalam masa pubertas atau masa peralihan sehingga banyak diantara mereka yang masih mencoba-coba melakukan sesuatu yang mereka anggap baru meskipun hal tersebut tidak sesuai norma yang ada. Salah satunya adalah tidak menaati tata tertib madrasah yang ditunjukkan dengan sering terlambat datang ke sekolah, tidak memakai atribut sesuai dengan yang telah ditentukan, masih bermalasmalasan ketika mengikuti shalat dzuhur berjamaah, kurang memperhatikan slogan 5S terlebih lagi saat berpapasan dengan guru ketika berpapasan. Karenanya, proses internalisasi nilai-nilai pendidikan karakter berupa penanaman nilai-nilai pendidikan akhlak mulia pada peserta didik sehingga diharapkan peserta didik dapat memiliki akhlak yang mulia baik di sekolah, rumah maupun masyarakat luas. Tolak ukur keberhasilan pendidikan tidak hanya dinilai dari tingkat kelulusan dengan nilai akademik yang baik saja, tetapi juga pada akhlak mulia dan moral yang baik peserta didik. Akhlak dan moral harus menjadi ruh pembinaan pendidikan di Indonesia. Sejalan dengan hal tersebut, proses internalisasi Pendidikan Agama Islam (PAI) dalam pembinaan akhlak dalam pembelajaran dapat berupa pengembangan model audio pendidikan karakter untuk meningkatkan sikap religius, jujur, disiplin, toleran, kerja keras, cinta damai, tanggung-jawab, dan sebagainya (Kosim, 2019). Dianti (2016) dalam penelitiannya menyebutkan bahwa upaya mengintegrasikan pendidikan karakter dibutuhkan sebuah perencanaan, pelaksanaan, dan adanya evaluasi pembelajaran.

\section{Metode Penelitian}

Penelitian kualitatif ini menggunakan pendekatan fenomenologis. Pendekatan ini menjadi pilihan dengan beberapa pertimbangan. Pertama, judul penelitian berhubungan dengan proses internalisasi nilai-nilai pendidikan karakter, sehingga memerlukan wawancara mendalam untuk dapat mengungkap tentang bagaimana siswa melakukan internalisasi nilai-nilai karakter dalam dirinya dan nilai-nilai apa saja yang telah berhasil diaktualisasikan dalam perilakunya. Kedua, obyek penelitian adalah persepsi atau pandangan individu tentang nilai-nilai karakter yang diinternalisasikan dan cara melakukan internalisasi nilai-nilai karakter tersebut.

Penelitian ini dilaksanakan di SMPN 1 Bantaran di Desa Tempuran Kecamatan Bantaran Kabupaten Probolinggo. Lokasi SMPN 1 Bantaran dipilih sebagai tempat penelitian karena sekolah ini memiliki keunikan dalam proses internalisasi pendidikan karakter. Subyek penelitian adalah kepala sekolah, guru, dan siswa di SMPN 1 Bantaran. Penentuan subyek penelitian dilakukan dengan purposive sampling. Prosedur penelitian ini mengacu pada tahapan penelitian menggunakan grounded theory menggunakan lima fase dalam membangun teori. Kelima tahap tersebut meliputi pengembangan 
konseptual, operasionalisasi, aplikasi, konfirmasi atau diskonfirmasi, dan perbaikan terus-menerus dan pengembangan.

Data penelitian ini diperoleh dengan teknik: pengamatan nonpartisipan, wawancara mendalam, dan dokumentasi. Pengamatan nonpartisipan artinya peneliti tidak berada pada posisi sebagai kepala sekolah, guru, maupun siswa, namun peneliti hanya mengikuti aktivitas yang dilakukan di sekolah lokasi penelitian. Pengamatan non partisipan dilakukan dengan cara peneliti berada di lokasi penelitian untuk melakukan pengamatan terhadap aktivitas aktor yang ada di sekolah yang diamati. Pengamatan dilaksanakan terhadap kultur sekolah, manajemen sekolah, ekstra kurikuler, pembelajaran, aktivitas siswa di sekolah. Wawancara mendalam dilakukan dengan kepala sekolah, guru, dan siswa. Wawancara dilakukan sampai dapat ditemukan sejumlah fenomena yang diperlukan. Metode dokumentasi dilakukan dengan cara menyelidiki benda-benda tertulis seperti visi misi, administrasi pembelajaran guru, dan program sekolah.

\section{Hasil dan Pembahasan}

Internalisasi pendidikan karakter dalam PAI adalah menanamkan nilainilai religius sehingga siswa menjadi pribadi yang memiliki moralitas dan akhlak sesuai dengan Al-Qur'an dan hadits. Proses ini dibutuhkan habituasi atau pembiasaan pada diri siswa yang perlu dilakukan secara terus-menerus sehingga bisa terbangun kesadaran diri. Dalam hasil penelitian ini ditemukan beberapa hal terkait internasilasi pendidikan dalam pembelajaran PAI.

\subsection{Internalisasi pendidikan karakter dalam pembelajaran PAI}

Internalisasi pendidikan karakter dalam pembelajaran PAI dilakukan dalam beberapa tahapan. Pertama, aspek penerimaan nilai. Siswa membiasakan diri untuk mendapatkan pengetahuan nilai yang baik dari guru agama pada saat pembelajaran di kelas. Pengetahuan nilai ini diperkuat dengan keteladanan yang diberikan guru agama dan guru bidang studi yang lain dalam setiap aktifitas keseharian di sekolah. Kedua, aspek merespon nilai pengetahuan baik secara langsung maupun berupa keteladanan yang diperoleh siswa dalam budaya religius di sekolah. Respon yang akan diterima dengan siswa dan diinternalisasikan dalam keseharian. Ketiga, proses seleksi nilai. Siswa akan merespon dan melakukan seleksi atas setiap pengetahuan nilai yang mereka peroleh. Apakah pengetahuan yang diterima tersebut baik dan memiliki manfaat atau apakah nilai-nilai itu dianggap bertentangan dengan norma dan kebiasaan selama di lingkungan luar sekolah. Keempat, proses penghayatan nilai. Nilai yang direspon dengan baik akan dihayati untuk membangun kesadaran dalam mengimplementasikannya. Kelima, proses 
penerapan nilai atau aktualisasi nilai. Setiap nilai yang diterima dan dihayati diaplikasikan dengan penuh kesadaran.

Internalisasi pendidikan karakter dalam pembelajaran PAI di SMPN 1 Bantaran adalah nilai kepedulian, tanggung jawab, kesadaran, kejujuran dan nilai cinta ilmu. Hal ini digunakan untuk menjadikan siswa lebih peduli dan memiliki tanggung jawab, sehingga nantinya siswa mempunyai kepribadian yang baik dan unggul. Dengan adanya nilai yang tertanam akan berdampak pada kepribadian siswa baik di sekolah maupun di masyarakat. Harapannya dengan kepribadian unggul siswa nantinya siap menjadi pemimpin atau di masa depan.

Wujud penanaman nilai pendidikan karakter di SMPN 1 Bantaran adalah kegiatan masa orientasi sekolah (MOS) yang digunakan untuk melatih dan membina siswa sejak awal masuk, kegiatan peringatan hari-hari besar diperingati dengan mengadakan event-event yang bertema keagamaan seperti sholawatan antar kelas, dan kurikulum yang disesuikan dengan kurikulum keagamaan. Dengan menyesuaikan kurikulum maka pembelajaran yang ada di SMPN 1 Bantaran mengintegrasikan antara ilmu pengetahuan umum dengan nilai-nilai karakter dan ilmu agama.

Pendidikan karakter juga diajarkan melalui kegiatan pembiasaan diri, baik yang bersifat rutin, spontan maupun keteladanan. Pembiasaan rutin, yaitu kegiatan yang dilakukan secara terjadwal, meliputi upacara bendera, senam, doa bersama, ketertiban, pemeliharaan kebersihan (Jumat Bersih), dan kesehatan diri. Pembiasaan spontan yaitu kegiatan tidak terjadwal dalam kejadian khusus, meliputi pembentukan perilaku memberi senyum, salam, sapa, membuang sampah pada tempatnya, budaya antri, mengatasi silang pendapat (pertengkaran), saling mengingatkan ketika melihat pelanggaran tata tertib sekolah, kunjungan rumah, kesetiakawanan sosial, dan anjangsana. Pembiasaan keteladanan adalah kegiatan dalam bentuk perilaku sehari-hari, meliputi berpakaian rapi, berbahasa yang baik, rajin membaca, memuji kebaikan dan keberhasilan orang lain, datang tepat waktu (Sofanudin, 2015)

Dengan demikian, siswa di SMPN 1 Bantaran menginternalisasikan nilai-nilai religius dalam proses pembelajaran di sekolah berupa pembiasaan pada aspek religius, kejujuran, tanggung jawab, kedisplinan kesopanan dan saling menghargai menjadi budaya tersendiri di lingkungan SMPN 1 Bantaran. Hal ini sejalan dengan hasil penelitian Sunarti dan Zamroni (2009) bahwa bahwa internalisasi nilai-nilai karakter dapat dilakukan dengan pendekatan komprehensif melalui integrasi dalam kultur sekolah dan pembelajaran. Pendekatan komprehensif dalam kultur sekolah dilakukan melalui pembiasaan dan keteladanan, sedangkan integrasi dalam pembelajaran dilakukan dengan pendekatan kontekstual (Sunarti, dkk, 2009). 


\subsection{Metode internalisasi pendidikan karakter dalam pembelajaran PAI di SMPN 1 Bantaran}

Proses internalisasi pendidikan karakter dalam pembelajaran PAI di SMPN 1 Bantaran mengajarkan metode dalam mendidik karakter sehingga anak didik memiliki gagasan konseptual tentang perilaku yang bisa dikembangkan dalam mengembangkan karakter pribadinya. Di SMPN 1 Bantaran, pendidikan karakter bertujuan untuk membentuk insan kamil yang mempunyai keseimbangan kecerdasan baik kecerdasan intelektual, spiritual maupun emosional. Ketiga bentuk kecerdasan ini diintegrasikan dalam semua mata pelajaran sehingga pengetahuan nilai itu bisa diperoleh dari semua guru di SMPN 1 Bantaran.

Umumnya pelaksanaan internalisasi pendidikan agama Islam pada saat diadakan di kelas selama proses belajar mengajar. Kegiatan dimulai dengan guru membimbing siswa untuk berdoa dan perlahan melihat reaksi siswa. Guru akan mengulangi doa jika dirasakan bahwa siswa belum merasa nyaman atau belum berkonsentrasi pada suasana kelas. Pengulangan dilakukan sehingga siswa dapat memperoleh antusiasme untuk mempelajari materi (Wahyudi \& Huda, 2019)

Nilai kedisiplinan yang diterapkan di SMPN 1 Bantaran dimulai dari kesadaran guru tentang pentingnya kedisiplinan sebagai keteladanan bagi peserta didik. Kedisiplinan terlihat dari jadwal masuk dan pulang sekolah, proses pembelajaran, pemenuhan setiap peraturan sekolah yang harus dilaksanakan bagi semua warga sekolah termasuk guru dan kepala sekolah, dan pelaksanaan sholat berjamaah yang dilakukan secara kontinu.

Metode pendidikan karakter di SMPN 1 Bantaran dengan mengadakan kegiatan keagamaan seperti hadroh dan shalat dhuha bergilir digunakan untuk memberikan ketrampilan khusus kepada anak didik untuk bekal di masa depan. Dengan menyesuaikan kurikulum maka pembelajaran yang ada di SMPN 1 Bantaran mengintegrasikan antara ilmu pengetahuan umum dengan nilai-nilai karakter dan ilmu agama. Metode yang digunakan untuk menanamkan nilai pendidikan karakter di SMPN 1 Bantaran pada peserta didik antara lain adalah metode uswah al-hasanah, nasehat, ceramah, dan pembiasaan.

Kendala yang dihadapi dalam menanamkan nilai karakter melalui pembelajaran pendidikan agama Islam kepada anak didik antara lain: SDM yang ada, keadaan siswa yang setiap tahunnya berganti-ganti, komitmen dan input anak didik yang berasal dari berbagai keluarga yang pluralis dari pedagang, buruh tani dan pegawai. Hambatan tersebut sebenarnya dapat diatasi dengan melakukan hal-hal sebagai berikut: guru harus melakukan kontrak belajar dengan siswa, melibatkan peran orang tua, penugasan siswa, menjadi motivator dan inspirator. 
Dalam pandangan Kosim (2019) pengembangan pembelajaran karakter meliputi beberapa hal. Pertama, pelaksanaan pembelajaran pendidikan karakter khususnya pendidikan karakter khususnya pada aspek kedisiplinan di sekolah dasar kelas tinggi saat ini. Kedua, mengembangkan model audio pendidikan karakter untuk siswa sekolah dasar kelas tinggi agar dapat meningkatkan sikap kedisiplinan. Ketiga, keefektifan model audio pendidikan karakter yang dikembangkan dalam meningkatkan sikap kedisiplinan siswa sekolah dasar kelas tinggi.

\subsection{Evaluasi pendidikan karakter melalui PAI pada peserta didik di SMPN 1 Bantaran}

Evaluasi dilaksanakan untuk mengetahui hasil yang dicapai benar-benar sesuai dengan rencana yang telah disusun. Pengetahuan terhadap hasil yang dicapai tersebut memerlukan informasi tentang tingkat pencapaian hasil. Informasi ini dapat diperoleh melalui komunikasi dengan bawahan, khususnya laporan dari bawahan atau observasi langsung. Evaluasi terhadap pendidikan karakter melalui pembelajaran pendidikan agama Islam dilakukan dengan berbagai cara, antara lain: observasi langsung, jurnal dan sebagainya.

Evaluasi untuk pendidikan karakter melalui PAI dapat dilakukan dengan pengamatan/observasi langsung, hasil penugasan, partisipasi kegiatan, dan lain-lain. Rubrik penilaian dapat berupa jurnal siswa, lembar observasi dan check list angket siswa. Di samping itu, evaluasi pendidikan karakter sifatnya juga berlangsung kontinu, terlebih lagi evaluasi pendidikan karakter yang dilakukan dengan pembelajaran PAI. Tagihan keagamaan seperti hafal asma' al-husna, doa-doa penting sebanyak 10 dan 15 surah pendek merupakan salah satu evaluasi tahunan untuk syarat kenaikan kelas anak didik yang dijadikan salah satu alat untuk mengevaluasi pendidikan karakter peserta didik. Jika lulus hafalan dan kegiatan keagamaan tersebut, maka dapat dikatakan telah tertanam nilai-nilai karakter kepada diri peserta didik.

Ada berbagai hambatan pada internalisasi PAI. Umumnya kebingungan guru adalah dalam menentukan indikator untuk menentukan keberhasilan anak dalam menyerap materi yang telah diajarkan. Kurangnya pengetahuan guru tentang sifat anak-anak dengan kebutuhan khusus (dalam hal ini kasus keterbelakangan mental) dan psikologi umum perkembangan anak juga menjadi faktor penghambat. Berikutnya, kurikulum pendidikan yang cukup luas dan memberatkan guru agama Islam karena tidak relevan dengan kondisi dan karakteristik siswa yang mengalami keterbelakangan mental. Disamping itu, kurangnya kegiatan pengembangan kompetensi untuk guru agama Islam untuk siswa berkebutuhan khusus (terutama untuk anak-anak retardasi mental) dan lemahnya sosialisasi dari pusat tentang kondisi siswa yang mereka pegang hari ini. Tidak adanya buku pendukung yang memfasilitasi guru dalam 
melaksanakan proses pembelajaran pendidikan Islam sehingga bahwa guru harus kreatif dan inovatif dalam membuat program pembelajaran pendidikan Islam juga bisa menghambat internalisasi PAI. Lalu, hambatan lainnya adalah fasilitas dan pendukung prasarana dan media pembelajaran baik dari sekolah dan bahkan pusat untuk mendukung proses pembelajaran PAI (Wahyudi \& Huda, 2019).

Dari hasil penelitian di atas maka karakter merupakan suatu nilai dasar yang dapat membangun kepribadian seseorang. Hal tersebut terbentuk baik karena pengaruh hereditas maupun pengaruh lingkungan, yang membedakannya dengan orang lain, serta di wujudkan dalam sikap dan perilakunya dalam kehidupan sehari-hari. Seseorang dapat dikatakan berkarakter baik atau unggul karena selalu berusaha melakukan hal-hal yang terbaik terhadap Tuhan Yang Maha Esa, diri sendiri, sesama manusia, lingkungan bahkan terhadap bangsa dan negara. Nilai-nilai karakter yang dapat diidentifikasi lumayan banyak, namun paling tidak terdapat nilai-nilai inti (core values) yaitu nilai karakter untuk personal (jujur dan cerdas) dan nilai karakter untuk sosial (tangguh dan peduli) (Gafur, 2012).

Internalisasi nilai-nilai pendidikan karakter terjadi melalui pembiasaan dan keteladanan. Pendidikan karakter dimaksudkan untuk menanamkan nilainilai kebaikan sebagai dasar untuk pengembangan pribadi selanjutnya. Pendidikan karakter bagi anak usia dini adalah membentuk mental dan karakter bangsa di masa yang akan datang (Cahyaningrum, Sudaryanti, \& Purwanto, 2017). Internalisasi nilai-nilai karakter yang baik merupakan suatu sistem yang berupaya untuk menanamkan nilai-nilai luhur kepada peserta didik: pengetahuan, kesadaran atau kemauan, dan tindakan untuk melakukan nilai-nilai tersebut. Dalam pelaksanaannya, semua komponen sekolah harus dilibatkan, isi kurikulum, proses pembelajaran dan penilaian, penanganan atau pengelolaan mata pelajaran, pengelolaan sekolah, pelaksanaan aktivitas atau kegiatan kokurikuler, pemberdayaan sarana prasarana, pembiayaan dan etos kerja seluruh warga sekolah.

Dalam pendidikan karakter, segala sesuatu yang dilakukan guru harus mampu mempengaruhi berkembangnya karakter peserta didik karena guru idealnya menunjukan keteladanan. Segala hal tentang perilaku guru/dosen hendaknya menjadi contoh peserta didik, misalnya dalam berbicara, menyampaikan materi, dan berbagai hal terkait lainnya. Tujuan internalisasi nilai-nilai karakter adalah membentuk kepribadian peserta didik agar menjadi warga masyarakat yang baik, dan warga negara yang baik. Sebagai seorang pendidik, internalisasi pendidikan karakter bisa berbasis nilai pada diri yaitu dilakukan melalui sistem penilaian yang objektif dan transparan. Hal ini akan berguna untuk memupuk kejujuran, kedisiplinan, dan tanggung jawab pada diri siswa (Otaya, 2014; Marjuni, 2015). 


\section{Kesimpulan}

Penelitian ini telah mengungkap adanya nilai-nilai pendidikan karakter yang ditanamkan di sekolah melalui Pendidikan Agama Islam (PAI) berupa nilai kejujuran, taat kepada agama, disiplin, kerjasama, toleransi, cinta ilmu, kepedulian, dan tanggung jawab. Wujud penanaman nilai pendidikan karakter di SMPN 1 Bantaran menggunakan metode keteladanan dan pembiasaan dengan mengadakan kegiatan keagamaan yang dimaksudkan untuk membekali anak didik dengan keterampilan dan keteguhan akhlak di masa depan. Kegiatan evaluasi internalisasi pendidikan karakter melalui PAI dapat dilakukan dengan cara mengamati siswa secara langsung, melalui hasil penugasan, keterlibatan siswa dalam kegiatan, dan lain-lain. Internalisasi pendidikan karakter di SMPN 1 Bantaran dilihat dari tiga nilai, yaitu nilai ibadah, akhlak (perilaku) dan kedisiplinan. Ibadah wajib dilakukan karena merupakan ketaatan universal kepada sang pencipta, akhlak yang baik wajib dipunyai oleh anak didik karena mereka berinteraksi dengan orang lain dalam masyarakat, sedangkan kedisiplinan merupakan manifestasi dari nilai ibadah.

\section{Daftar Pustaka}

Astra, I. M. (2018). Character building in physics learning for Indonesia children. Journal of Physics: Conference Series, 1040(1), 012043. DOI:10.1088/1742-6596/1040/1/012043 1234567890

Bali, M. M. E I., \& Fadilah, N. (2019). Internalisasi karakter religius di Sekolah Menengah Pertama Nurul Jadid. Jurnal MUDARRISUNA: Media Kajian Pendidikan Islam, 9(1), 1-25.

Cahyaningrum, E. S., Sudaryanti, S., \& Purwanto, N. A. (2017). Pengembangan nilai-nilai karakter anak usia dini melalui pembiasaan dan keteladanan. Jurnal Pendidikan Anak, 6(2), 203-213. DOI:10.21831/jpa.v6i2.17707

Dianti, P. (2016). Integrasi pendidikan karakter dalam pembelajaran pendidikan kewarganegaraan untuk mengembangkan karakter siswa. Jurnal Pendidikan Ilmu Sosial, 23(1). DOI:10.17509/jpis.v23i1.2062

Fitri, A. (2018). Pendidikan karakter perspektif Al-Quran hadits. TA'LIM : Jurnal Studi Pendidikan Islam, 1(2), 258-287.

Gafur. (2012). Internalisasi nilai-nilai pendidikan karakter dalam silabus Pendidikan Agama Islam di perguruan tinggi. Seminar dan Lokakarya Pendidikan Karakter Berbasis Masjid, 1-7. 
Jumala, N. J. N., \& Abubakar, A. (2019). Internalisasi nilai-nilai spritual Islami dalam kegiatan pendidikan. Jurnal Serambi Ilmu, 20(1), 160173.

Kosim, A. (2019). Internalisasi pendidikan karakter berbasis school culture. Jurnal Wahana Karya Ilmiah, 3(1), 240-251.

Ma'arif, M. A., \& Hamid, A. (2018). Pembelajaran berbasis karakter pendidikan Islam. An-Nisa, 11(1), 93-104.

Marjuni, M. (2015). Pilar-pilar pendidikan karakter dalam konteks keislaman. Auladuna: Jurnal Pendidikan Dasar Islam, 2(1), 154-163.

Mubarok, A. Z. (2019a). Model pendekatan pendidikan karakter di pesantren terpadu. Ta'dibuna: Jurnal Pendidikan Islam, 8(1), 134-145.

DOI:10.32832/tadibuna.v8i1.1680

Mubarok, A. Z. (2019b). Model pendidikan pesantren terpadu dalam membina karakter di era globalisasi. Quality, 7(1), 191-204.

Nurajizah, N. B., \& Rahayu, C. P. B. (2019). Model Hidden Curriculum untuk mengembangkan karakter disiplin pada peserta didik. JURKAM: Jurnal Konseling Andi Matappa, 3(1), 23-27.

Otaya, L. G. (2014). Pendidikan karakter berbasis nilai. Nadwa, 8(1), 75-94. DOI:10.21580/nw.2014.8.1.571

Prasetiya, B., Rofi, S., \& Setiawan, B. A. (2018). Penguatan nilai ketauhidan dalam praksis pendidikan Islam. Journal of Islamic Education, 3(1), 115.

Sari, N. K., \& Puspita, L. D. (2019). Implementasi pendidikan karakter di sekolah dasar. Jurnal Dikdas Bantara, 2(1), 57-72.

Sofanudin, A. (2015). Internalisasi nilai-nilai karakter bangsa melalui mata pelajaran Pendidikan Agama Islam pada SMA Eks-RSBI di Tegal.

Jurnal SMART (Studi Masyarakat, Religi, dan Tradisi), 1(2), 151-163. DOI:10.18784/smart.v1i2.248.

Sunarti, T., Zamroni, dkk. (2009). The internalization and actualization of character values in the students of junior high schools in 
phenomenological perspective. Jurnal Pembangunan Pendidikan: Fondasi dan Aplikasi, 181-195.

Wahyudi, A., \& Huda, M. (2019). Internalization of Islamic values for students with special needs in special school education institutions (SLB ). Al-Hayat: Journal of Islamic Education, 3(1), 90-97.

Wijayanti, W., \& Fatimah, N. (2018). Aktualisasi pendidikan karakter di madrasah. An-Nisa', 11(1), 83-92.

Yunarti, Y. (2017). Pendidikan ke arah pembentukan karakter. Tarbawiyah Jurnal Ilmiah Pendidikan, 11(2), 262-278. 